\title{
Review Article \\ A Short Review on Heterocyclic Compounds Showing Anti-Breast Cancer Activity
}

\author{
R. Ayana ${ }^{1 *}$, B. Vijayakumar ${ }^{1}$, P. Athulya ${ }^{1}$, V. S. Anjana ${ }^{2}$, K. V. Vismaya ${ }^{3}$, G. Swarnalatha ${ }^{4}$ \\ ${ }^{1}$ Department of Pharmaceutical Chemistry, Grace College of Pharmacy, Palakkad-678004, Kerala, India \\ ${ }^{2}$ Department of Pharmaceutical Chemistry, The Dale View College of Pharmacy and Research \\ Centre, Punalal, Trivandrum - 695 575, Kerala, India \\ ${ }^{3}$ Department of Pharmaceutical Chemistry, Nehru college of Pharmacy, Pampady, Thiruvilwamala, \\ Thrissur- 680 588, Kerala, India \\ ${ }^{4}$ Department of Pharmaceutical Chemistry, Mahathi college of Pharmacy, C.T.M, Angalu - CTM \\ Road, Madanapalle, Andhra Pradesh - 517325, India
}

Received 26 March 2021, accepted in final revised form 7 July 2021

\begin{abstract}
Breast cancer (BC) is the most common cancer for females, and its incidence tends to increase year by year. Currently, the backbone of therapy for BC is mainly chemotherapy; however, its toxicity in normal cells and acquired tumor resistance to the drug users are considered the main barriers. Therefore, there is still an urgent need for the development of more effective and safer anti-BC agents. Based on previous reference documents in recent years, this review covers the work reported on the anti-BC compounds classified according to the structures. This review summarized significant anti-BC compounds organized by functional groups according to the animal model data, although there would be some limitations. This review highlights the properties of new compounds having promising anti$\mathrm{BC}$ properties, which may be proven to be more effective and selective, and possibly free of unwanted side effects. The reviewed compounds represent an interesting possibility of overcoming $\mathrm{BC}$ and reducing the percentage of patients with an inadequate response to drug therapy.
\end{abstract}

Keywords: Anti-breast cancer; Quinoline; Pyrimidine; Indole.

(c) 2021 JSR Publications. ISSN: 2070-0237 (Print); 2070-0245 (Online). All rights reserved. doi: http://dx.doi.org/10.3329/jsr.v13i3.52626 J. Sci. Res. 13 (3), 1075-1098 (2021)

\section{Introduction}

Cancer is taken as the most severe health problem all over the world. Even though the advancement of novel chemotherapeutic agents has remarkably progressed within the last few years, achievement in developing non-cytotoxic targeted drugs with very few side effects has happened only in the last decade. Despite these advances, most tumors like breast and ovarian are still difficult, and survival rates remain seriously low. Hence, discovering new potent, safe and selective antitumor agents is strongly needed [1]. Breast

\footnotetext{
*Corresponding author: ayanaraj67730@gmail.com
} 
cancer is one of the most commonly diagnosed cancers, comprising $23 \%$ of all female cancers and the second leading cause of cancer deaths in women worldwide [2].

Breast cancer is considered the second cause of cancer-related deaths in women all over the world. The US-FDA has approved multiple drugs for the treatment of breastrelated malignancies. The frequent emergence of resistances leads to the urgent need for newer moieties to overcome such problems [3]. As one of the deadliest cancers, breast cancer treatment requires efficacious drugs and improved therapeutic strategies. Although, the expansion of new drugs is exceedingly long-term and costly. Thus, identifying new uses of existing non-oncology or oncology drugs in treating breast cancer is becoming an essential step toward developing better treatment strategies and improving overall outcomes [4]. Breast cancer is considered to be one of the most widespread cancers that have an impact on women all over the world. It begins typically from milk ducts (ductal cancer) or the lobules that provide them with milk (lobular cancer), and then the tumor can extend to the entire body. It is worth mentioning that breast cancer represents $16 \%$ of all women's cancers and $18.2 \%$ of cancer deaths worldwide. Despite all the extensive efforts made in this field, cancer is a leading reason for mortality in the world.

As the better frequently occurring cancer in women worldwide, breast cancer constitutes a Formidable public health challenge globally. Approximately 200,000 cases of invasive breast cancer and 54,000 in situ breast cancer cases will be diagnosed in the United States this year. It is expected that 40,000 women will die from distant relapses of their disease. Breast cancer is the second leading cause of cancer death in females after lung cancer. The incidence of breast cancer increases with age, and more than $50 \%$ of all women diagnosed are 65 or older. 1 It is expected that by the year 2030, $20 \%$ of the US population will be $>65$ years old, and thus an ever-growing number of women will be diagnosed with this disease [5].

We have focused on several research articles that proved the anti-cancer activity using different experimentation procedures, further giving an excellent future reference for many developing procedures. Quinoline nucleus shows a very vast activity on anticancer activity; various fused quinolines were studied for their intercalative DNA binding properties [6,7]. Pyrimidine is another heterocyclic compound we focused on that exhibited a perfect result of the activity we are searching for. It is also a developing nucleus derivative for anti-breast cancer activity. Finally, indole was selected and searched. It showed a fundamental novel derivative that acts against breast cancer. This gives a clear understanding of how well a nitrogen-containing heterocycle imparts its activity in inhibiting the pathophysiology of breast cancer.

\section{The Quinoline Functional Group}

Quinoline is a nitrogen-containing heterocyclic aromatic compound. Pharmacologically active substances display a broad range of biological activity [8-11]. Quinoline has been found to possess antimalarial, antibacterial, antifungal, anticonvulsant, anti-inflammatory, and analgesic activity. Quinoline derivatives are pharmacologically important heterocycles that have been studied mainly for their antiproliferative properties. In 
addition, quinoline derivatives find use in the synthesis of fungicides, virucides, biocides, alkaloids, and flavoring agents. Quinolines also act as carbonic anhydrase inhibitors. On the other side, numerous fused systems of quinolines were deliberated for their intercalative DNA binding properties. A literature survey discloses that the anti-cancer activity is due to the intercalation between the base pairs of DNA and intrusion. The average working of enzyme topoisomerase II is included in the breaking and releasing DNA strands. The antitumor drugs that intercalate DNA are of growing interest in the field of anti-cancer derivatives [12].<smiles>O=c1ncccc2ccccc12</smiles>

Dual inhibitors of aromatase (CYP19) and aldosterone synthase (CYP11B2) are proposed as a novel strategy for the adjuvant therapy to reduce the CVD risk for postmenopausal breast-cancer patients increases the risk of cardiovascular diseases (CVD), which is accepted to be caused by the unusually high concentrations of aldosterone as an effect of the estrogen deficiency. By merging the final structural features of CYP11B2 and CYP19 inhibitors into a standard template, a series of pyridinylmethyl substituted 1,2,5,6-tetrahydro-pyrrolo [3,2,1-ij]quinolin-4-ones were designed and synthesized in inhibition of one enzyme. At the same time, it led to a decline for the other enzyme. The compromise of this dispute led to compounds, Compound 1-4 as vigorous and selective dual inhibitors of CYP19 and CYP11B2, mainly compound 3, which showed $\mathrm{IC}_{50}$ values of 32 and $41 \mathrm{nM}$ for CYP19 and CYP11B2, respectively, and a high specificity toward CYP17 and CYP11B1. Finally, this is considered for further evaluation in vivo [13].<smiles>COc1ccc(C(C)c2ccncc2)cc1</smiles>

$1-8-(-\mathrm{CH} 2 \mathrm{CH} 2-), 2-=0$ 1<smiles>OC(c1ccncc1)c1cccc(Cl)c1</smiles>

$1-8-(-\mathrm{CH} 2 \mathrm{CH} 2-), 2-=0$<smiles>Cc1cccc(C(O)c2ccncc2)c1</smiles>

$1-8-(-\mathrm{CH} 2 \mathrm{CH} 2-), 2-=0$

3<smiles>COc1cccc(C(C)c2ccncc2)c1</smiles>

1-8-(-CH2CH2-),2- $=0$

Some novel quinoline derivatives were designed and synthesized to assess their biological activities as anti-breast cancer agents and aromatase inhibitors. Cytotoxicity of quinolines 5a-g against human breast cancer MCF-7 and T47D cell lines were evaluated. All the compounds 5a-g were more cytotoxic against MCF-7 cells in comparison with those of T47D, which express aromatase mRNA less than MCF-7 cells. Their effects on 
aromatase activity are also described. Results showed that compound $\mathbf{5 b}$ inhibits aromatase enzyme activity more than the reference drug Letrozoa [14].<smiles>Ic1ccc(-c2cc(Cn3ccnc3)c3ccc(I)c(I)c3n2)cc1</smiles>

5a) $1=\mathrm{Ph}, 2=\mathrm{H}, 3=\mathrm{OM}$; 5b) $1=\mathrm{Ph}, 2=\mathrm{H}, 3=\mathrm{F}$; 5c) $1,2=\mathrm{Phenyl}, 3=\mathrm{OM}$; 5d) $1,2=\mathrm{Phenyl}, 3=\mathrm{F}$; 5e) $1,2=$ Cyclohexyl, $3=\mathrm{F}$; 5f) $1,2=\mathrm{H}, 3=\mathrm{OMe}$ and 5g) $1,2=\mathrm{H}, 3=\mathrm{OMe}$.

In a tryout to enhance anti-breast cancer activity, a new series of 4-piperazinyl quinoline derivatives based on the urea/thiourea scaffold was designed and synthesized by a pharmacophore hybrid proposal. They analyzed for their antiproliferative activity on three human breast tumor cell lines, MDA-MB468, MDA-MB231, and MCF7, also, in MCF10A and 184B5, two non-cancer breast epithelial cell lines. Among those 26 novel compounds examined, 6a-e showed significantly improved antiproliferative activity on breast cancer cells. The cancer cell-specific property of compound $\mathbf{d}$ demonstrated in cell culture stands in vivo test; this compound can be an excellent lead for effective and safe anti-cancer drugs [15].<smiles>[R]NC(=O)N1CCN(c2ccnc3cc([X])ccc23)CC1</smiles>

6a) $\mathrm{X}=\mathrm{Cl}, \mathrm{R}=\mathrm{Phenyl}$; 6b) $\mathrm{X}=\mathrm{Cl}, \mathrm{R}=2,6$ Dimethyl $-\mathrm{Phenyl}$; 6c) $\mathrm{X}=\mathrm{Cl}, \mathrm{R}=2,4,6$-Trichloro-phenyl; 6d) $\mathrm{X}=\mathrm{Cl}, \mathrm{R}=2$-morpholin-4-yl-ethyl and $\mathbf{6 e}) \mathrm{X}=\mathrm{CF}_{3}, \mathrm{R}=$ Naphthalen-1-yl.

Jafari et al. showed a new series of benzo- and tetrahydro benzo-[ $h]$ quinoline bearing a flexible (dimethylamino)ethylcarboxamide side chain designed and synthesized as DNA intercalating antitumor agents. The cytotoxic activity of the synthesized compounds was evaluated against four human cancer cell lines, including MCF-7, A2780, C26, and A549. Compound 6e showed significant cytotoxicity against all four human cancer cell lines with IC50 values ranging from 1.86-3.91 $\mu \mathrm{M}$. The interaction of the selected compounds showed significant cytotoxicity (7a-d) with calf thymus DNA (CT-DNA) was studied by 
UV and fluorescent spectroscopy. Compound 7c exhibited the most DNA intercalating effects among the series. Compound $\mathbf{6 e}$, which showed the most cytotoxic effect against A549 cancer cells, also exhibited stronger apoptotic induction activity than 7a and 7c. The docking was performed to study the DNA interaction properties of these compounds. Computational data showed that these compounds could interact with DNA as DNAintercalating agents [16].<smiles>Cc1nc(-c2cc(C(=O)NCCN(C)C)c3ccc4ccccc4c3n2)cc(I)c1C</smiles>

7a) $\left.\left.1=3=\mathrm{H}, 2=\mathrm{OCH}_{3} ; \mathbf{7 b}\right) 1=3=\mathrm{H}, 2=\mathrm{NHCOCH}_{3} ; \mathbf{7 c}\right) 1=3=\mathrm{H}, 2=\mathrm{CH}_{3}$ and 7 d) $1=2=\mathrm{H}, 3=\mathrm{OCH}_{3}$.

Liu et al. showed that camptothecin (CPT, 8), a quinoline compound, exhibits anticancer activity by trapping topoisomerase I (topo I)DNA cleavage complexes. However, this complexation is reversible. Besides, this drug binds tightly with the human serum albumin protein and decreases its bioavailability. All these drawbacks were encouraged by Liu et al. [17] to synthesize CPT analogs along with their evaluation against several cancer cell lines (BT483, PC3, SKHep, CE81T, AGS, RCC786-O) and the anti-breast cancer activity (BT483, MB-231, Hs578T, MB-157, SK-BR-3, MCF7) of compound 9. Compound 9 exhibited anti-cancer activity against all cancers investigated with IC50 ranging between 1.1-10.6 $\mu \mathrm{M}$. For breast cancer cell lines, 9 displayed potency against all cancer cells (IC50 between 1.59 to $3.6 \mu \mathrm{M}$ ) with the most activity against BT483.
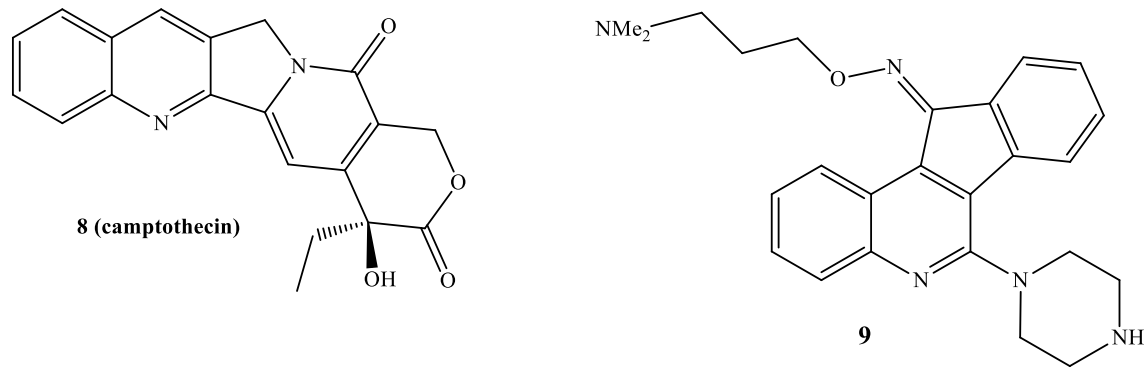

A set of hybrids between chalcone and quinoline pharmacophores (10-11) was prepared by Tseng et al. [18]. The prepared quinolinyl chalcone conjugates were evaluated in vitro against three breast cancer cells (MCF-7, MDA-MB-231, and SK-BR3) along with three non-small cell lung cancer cells (H1299, H460 and A549) and a normal mammary epithelial cell (H184B5F5/M10). Among the tested compounds, 11 proved to be the most potent with an $\mathrm{IC}_{50}$ value of fewer than $0.10 \mu \mathrm{M}$ against the growth 
of MDA-MB-231 and was non-cytotoxic to the normal mammary epithelial cell (H184B5F5/M10). Based on the mechanistic studies, it was observed that compound 11 induced cell cycle arrest at G2/M phase followed by activation of caspase-3, cleavage of PARP resulting in cell death.<smiles>[R][X]c1cccc(C/C=C/c2nc3ccccc3cc2-c2ccc(OC)cc2)c1</smiles>

$\mathrm{R}=\mathrm{H}, 4-\mathrm{F}, 4-\mathrm{OH}, 4-\mathrm{OMe}, 2$,4-di-OMe, 4- $\mathrm{NH}_{2}$<smiles>COc1ccc(-c2cc3ccccc3nc2/C=C/C(=O)[Al])cc1</smiles>

2,4-di-OMe, 4- $\mathrm{NH}_{2}$<smiles>COc1cccs1</smiles><smiles>Oc1ccccn1</smiles><smiles>Cc1sccc1N</smiles><smiles>Cc1ccc(Br)s1</smiles><smiles>CC=Cc1ccsc1</smiles>

$\operatorname{Ar}=$

The above work was further extended towards synthesis and antiproliferation activities of certain indeno [1,2-c] quinolone hybrids (compound 12) against BT483 and other cancer cell lines (Hela, AGS, A549, PC-3, SKHep and MRC-5) along with their DNA binding affinity and topoisomerases (topo I and topo II) inhibitory activities [19]. Compound 13 demonstrated stronger topo I/II inhibitory activity without any significant binding with the DNA. The antitumor evaluation of $\mathbf{1 3}$ in nude mice bearing subcutaneous breast cancer tumors revealed that the treatment with low $(10 \mathrm{mg} / \mathrm{kg})$ or high $(30 \mathrm{mg} / \mathrm{kg})$ doses dramatically diminished tumor growth.

Mohammadhosseini et al. [20] have described the synthesis and cytotoxic activity evaluation of a new series of N-pipearzinyl quinolones containing N-2-(furyl-2 or 3-yl)-2(chlorobenzyloxyimino)ethyl moiety. Preliminary screening indicated that compound $\mathbf{1 4}$ with $\mathrm{IC}_{50}$ values of 3.03, 11.9, and $2.2(\mu \mathrm{M})$ for MCF-7, MDA-MB-231, and T47D, respectively, demonstrated significant growth inhibitory potential against all evaluated cell lines. 


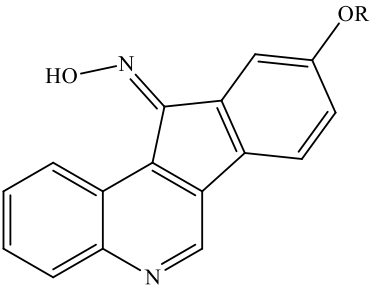

12

$\mathrm{R}=-\left(\mathrm{CH}_{2}\right)_{2} \mathrm{NMe}_{2},-\left(\mathrm{CH}_{2}\right)_{3} \mathrm{NMe}_{2}$,

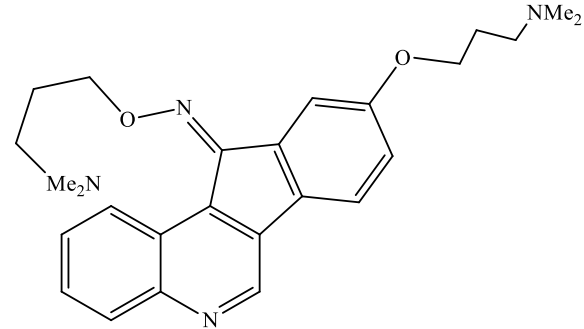

13

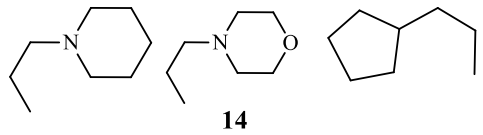

A series of novel 6,8-dibromo-2-aryl-2,3-dihydroquinolin-4(1H1) has been synthesized and evaluated in vitro (in MCF-7 BC cell lines). Potent growth inhibition of $50 \%\left(\mathrm{GI}_{\mathrm{F}}\right)$ was exhibited by compounds $\mathbf{1 5 - 1 8}$ and total growth inhibition (TGI) values compared with reference standard [21].

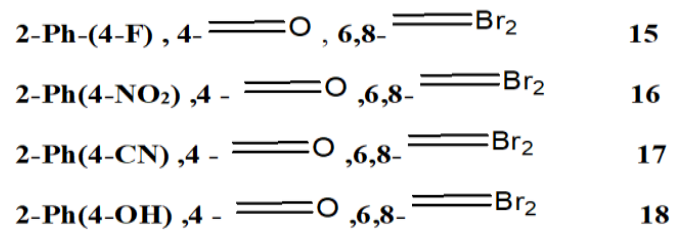

3-Amino- $N$-(3-chlorophenyl)-5-oxo-5,6,7,8-tetrahydrothien of $\quad[2,3 b]$ quinoline-2carboxamide (compound 19) as a putative phosphoinositide specific-phospholipase $\mathrm{C}-\mathrm{\gamma}$ enzyme inhibitor, affected the proliferation, morphology, and migration of a host of breast cancer cell lines, and arrests cell cycle in the G2/M phases [22].

$$
\text { ,5- }=0,19
$$

A new group of 4-(imidazolyl methyl) quinoline derivatives possessing a methylsulfonyl COX-2 pharmacophore at the para position of the $\mathrm{C}-2$ phenyl ring were designed and synthesized as selective COX-2 inhibitors, and in-vitro studies were carried out for anti-breast cancer agents. Only compound $20\left(\mathrm{IC}_{50}<5 \mu \mathrm{M}\right)$ was identified as the most potent in anti-breast cancer screening and selective COX-2 inhibitor as well as the most cytotoxic agent against MCF-7 cells [23].

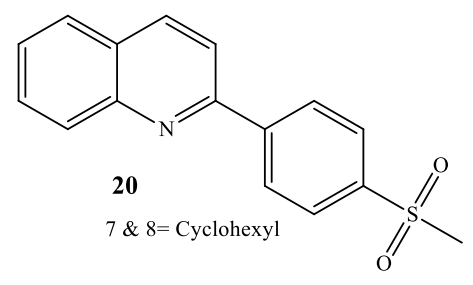


Estrogen deficiency results in significantly elevated aldosterone levels, which are a significant cause of cardiovascular diseases. Dual inhibition of CYP19 and CYP11B2 (aldosterone synthase) is a promising treatment for breast cancer and coinstantaneous cardiovascular diseases. By incorporating important structural characteristic of known CYP19 and CYP11B2 inhibitors, they came after obtaining compounds 21 and 22 as selective dual inhibitors with $\mathrm{IC}_{50}$ values around 50 and $20 \mathrm{nM}$ toward CYP19 and CYP11B2, respectively. These compounds also showed good selectivity toward CYP11B1 (selectivity factors (IC50 CYP11B1/IC50 CYP11B2) around 50) and CYP17 (no inhibition) [24].

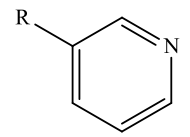

21

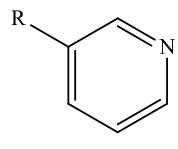

22

$1-\mathrm{CH}_{3,2}=\mathrm{O}, 7-\mathrm{OMe}$

$1-\mathrm{CH}_{3}, 2-\overline{=}, 1-\mathrm{C}_{2} \mathrm{H}_{5}, 3-\mathrm{COOH}, 4-\overline{=}, 6-\mathrm{F}$

Bharathkumar et al. [25] reported a new type of quinoline-based estrogen receptor alpha (ERa) ligands that were examined for their bioactivity against ERa-negative and ERa-positive cell lines. The most potent compound $\mathbf{2 3}$ displayed significant cytotoxicity against HepG2 and MCF-7 cells with a half-maximal inhibitory concentration $\left(\mathrm{IC}_{50}\right)$ value of 6 and $11 \mathrm{mM}$, respectively. Multiple reports have demonstrated the preparation of quinolones using a strong base like tertiary butoxide.

$$
\text { 2-Ph(4-NH }), 7-\mathrm{Cl}
$$

\section{The Pyrimidine Functional Group}

Pyrimidine ring is a heterocyclic organic aromatic compound like pyridine. One of the six-membered heterocyclics with two nitrogen atoms in the ring has the nitrogens at positions 1 and 3 in the ring. Pyrimidines, a significant heterocyclic compound, have a broad spectrum of bioactivities (antibacterial, anti-cancer, and anti-inflammatory, etc.) $[27,28]$.<smiles>C1=CNCCN1</smiles>

Pyrimidine and its derivatives play a significant role in drug discovery procedures and appreciate the chemical significance and biological activities. Pyrimidines are the backbone of many natural compounds like vitamins, liposacharides, and antibiotics. Pyrimidine is utilized as a parent substance to synthesize many different heterocyclic compounds and raw materials for drug synthesis. It is also critical in the theoretical development of heterocyclic chemistry and organic synthesis. Pyrimidine derivatives are 
essential in various biological activities, i.e., antihypertensive, anti-cancer, antimicrobial, anti-inflammatory, and antioxidant activity. This creates interest among researchers who have synthesized a variety of pyrimidine derivatives [29].

Docking-motivated synthesis of 5-aryl-3H-thieno[2,3- $d$ ] pyrimidin-4-ones (compound 24-25) was performed from the reaction of 2-aminothiophene-3- carbonitrile and formic acid [30]. The cytotoxicity evaluation of few compounds against breast cancer cell line (MCF-7), using sulforhodamine B (SRB) assay revealed good to the moderate activity of all the compounds with $\mathrm{IC}_{50 \mathrm{~s}}$ in micro-molar range (between 0.0544 to 0.0098 $\mu \mathrm{M}$ convert to $\mathrm{nM}$ ). The most significant cytotoxicity was observed for compound $\mathbf{2 6}$ $(\mathrm{IC} 50=0.0098 \mu \mathrm{M})$, a Schiff analog of thieno-pyrimidinone, which was more potent than even a control drug lapatinib $\left(\mathrm{IC}_{50}=0.0100 \mu \mathrm{M}\right.$ convert to $\left.\mathrm{nM}\right)$.

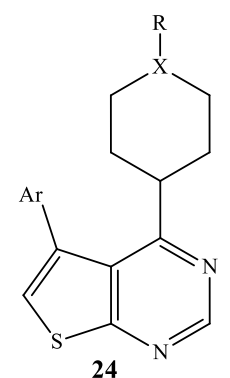

$\mathrm{X}=\mathrm{CH}, \mathrm{N} ; \mathrm{Ar}=4-\mathrm{Cl}-\mathrm{Ph}, 4-\mathrm{NO}_{2}-\mathrm{Ph}$

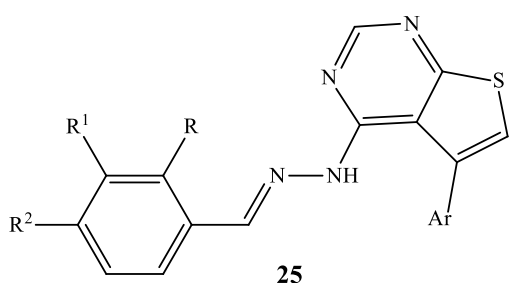

$\mathrm{R}=\mathrm{H}, \mathrm{OCH}_{3}, \mathrm{~N}\left(\mathrm{CH}_{3}\right) \mathrm{R}=\mathrm{H}, \mathrm{NO}_{2} ; \mathrm{R}^{1}=\mathrm{OCH}_{3}$

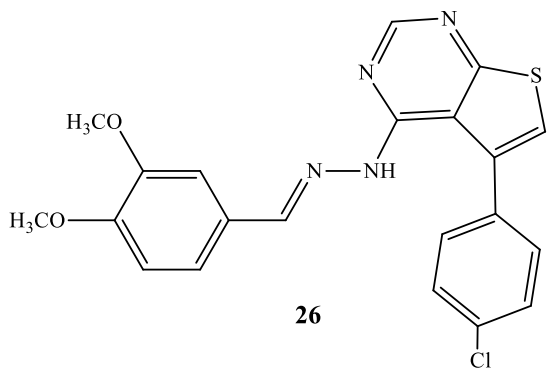

$\mathrm{R}=\mathrm{CH}_{2} \mathrm{Ph}, \mathrm{CH}_{3}, \mathrm{Ph}, 4-\mathrm{Cl}-\mathrm{Ph}, 4-\mathrm{OCH}_{3}-\mathrm{Ph}$

Another series of hybrids, viz., 2-pyridyl hexahydrocycloocta [4,5] thieno [2,3-d] pyrimidines (compounds 27), with different substituents at the C-4 position was synthesized by Kassab and Gedawy and tested their in vitro antiproliferative activity against 60 different human tumor cell lines representing leukemia, melanoma, and cancers of the colon, central nervous system, lung, ovary, kidney, prostate including breast [31]. Commonly, compounds carrying pyridyl moiety at the C-2 position were found to have better anti-cancer activity. Among these compounds, 28 was the most potent with growth inhibition percentage values of $89.23,22.41,6.17$, and $2.77,57.56$, and $30.07 \mu \mathrm{M}$ against MCF-7, MDAMB- 231, HS 578T, BT-549, T-47D, and MDA-MB-468 breast cell lines, respectively. 

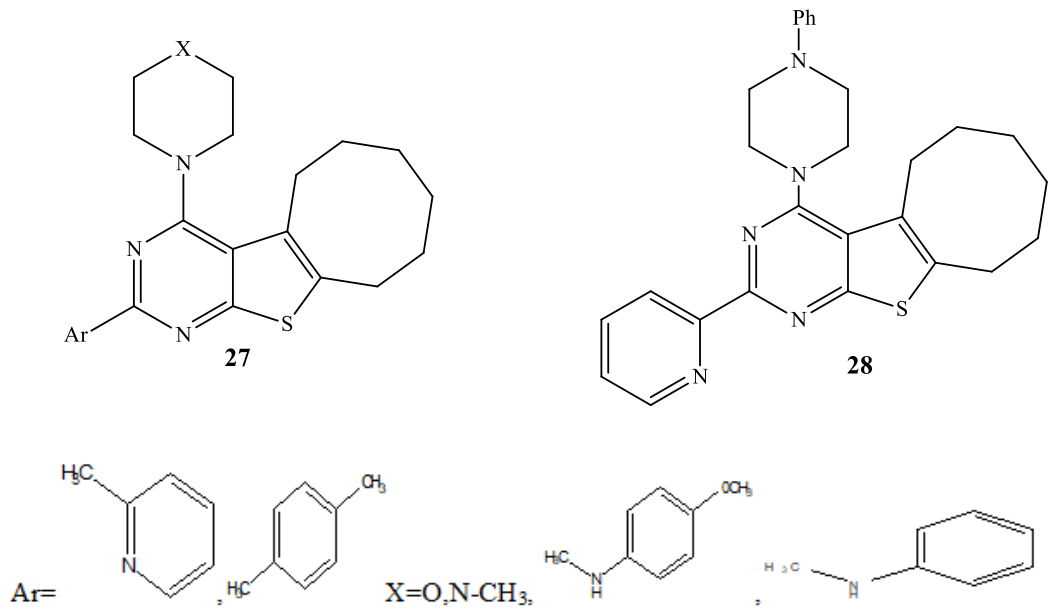

A series of new 1-aryl-4-benzylidenehydrazinyl-3-methylsulphanyl-pyrazolo[3,4d]pyrimidines 29a-p was synthesized. Majority of the test compounds given potent antitumor activity comparable to that of standard doxorubicin. The 1-phenyl series (29a-i) exhibited better anti-tumor activity than 1-(4-methoxyphenyl) series (29j-p). 4-[2-(4Fluorobenzylidene)hydrazinyl]-3-(methylsulphanyl)-1-phenyl-1H-pyrazolo[3,4-]

pyrimidine (6d) was one of the better active compounds in this work with IC50 equal to $7.5 \mathrm{nM}[32]$.

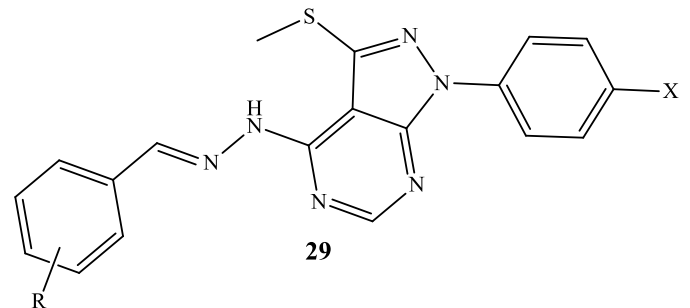

For 29a-i: $\mathrm{X}=\mathrm{H}, \mathrm{R}=4-\mathrm{NH}_{2}$, 4-Br, 4-Cl, 4-F, 2-OH, 3-OH, 4-OH, 3- $\mathrm{CH}_{3} \mathrm{O}, 2-\mathrm{Cl}-4-\mathrm{NO}_{2}$

For 29j -p: $\mathrm{X}=\mathrm{CH}_{3} \mathrm{O}, \mathrm{R}=4-\mathrm{Br}$, 4-Cl, 4-F, 2-OH, 3-OH, 4-OH, 4- $\mathrm{CH}_{3} \mathrm{O}$

Vascular endothelial growth factor (VEGF) and their receptor (VEGFR) are important for tissues and neovasculature physiological roles. VEGFR signaling is related to the development of pathological angiogenesis in different types of cancer growth, making it an interesting therapeutic target in cancer treatment. In the present work, they proved the synthesis of 1,4-disubstituted 1,2,3-triazoles and 1,2,4-triazolo[1,5a]pyrimidine derivatives through copper (I)-catalyzed azide-alkyne cycloaddition $(\mathrm{CuAAC})$ reaction and screened for their antitumor activity against MCF7 cells. Observed 1-(2'-ethoxy-4'-fluoro-[1,1'-biphenyl]-4-yl)-4-phenyl-1H-1,2,3-triazole (EFT) as major cytotoxic agent against MCF7 cell lines with a $1.69 \mathrm{MmIC50}$ value (structure 30). Further evaluation revealed that EFT induces cytotoxicity on Ishikawa, MDA-MB-231, and BT474 cells with IC50 values of $1.97,4.81$, and $4.08 \mu \mathrm{M}$, respectively. Although, EFT 
did not persuade cytotoxicity in ordinary lung epithelial (BEAS-2B) cells. Previous reports suggested that 1,2,3-triazoles are the inhibitors of VEGFR1 and, therefore, evaluated the effect of EFT on the expression of VEGFR1. The reports revealed that EFT reduces the expression of VEGFR1 in MCF7 cells. In conclusion, they pointed out a potent cytotoxic agent that reveals its antiproliferative activity by targeting VEGFR1 in breast cancer cells. The novel compound could serve as a lead structure in developing VEGFR1 inhibitors [33].

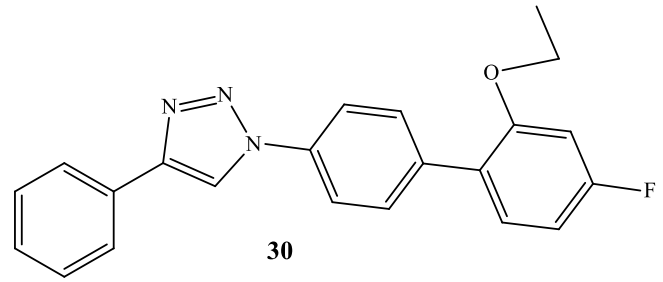

A series of novel substituted pyrazolo[3,4-d]pyrimidines were designed and synthesized, initiating with pyrimidinone derivative 1 . They are in vitro cytotoxicity against human breast adenocarcinoma (MCF-7) cell lines, have been analyzed, and almost tested compounds were showed potent cytotoxic activity against MCF-7 cell lines close to the activity of the commonly used cisplatin, anti-cancer drug. Treatment of MCF-7 cells with increased doses $(2,5,10,20 \mathrm{mg} / \mathrm{mL})$ of the tested compounds revealed that the activity of superoxide dismutase and the level of hydrogen peroxide were significantly increased, while the activities of catalase and glutathione peroxidase and the levels of reduced glutathione were remarkably lowered equated with control MCF-7 cells. In general, the acyclic nucleoside derivative (compound 31) revealed the highest anti-cancer activity among the other tested compounds [34].

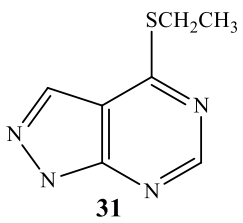

The human (h)-prune is a protein; it is one of the DHH protein superfamilies and shows cAMP phosphodiesterase activity. Its expanded action in breast, colorectal and gastric malignancies compares with the profundity of intrusion and a serious level of lymph-node metastasis. A solitary mechanism by which h-prune induces cell motility and metastasis measures through its phosphodiesterase action can be repressed by dipyridamole, and a pyrimido[5,4-d]pyrimidine simple. To accomplish the most intense agent having specific restraint of h-prune action, it is followed structural activity relationship procedures beginning from dipyridamole, and arranged eight new pyrimidopyrimidine derivatives. These compounds were synthesized for explicitness towards $h$ prune exercises in vitro in cell models by utilizing scintillation examine for cAMP-PDE action and transwell approach for two-dimensional cell movement in a top-down 
methodology of picking. It clearly shows that two pyrimido[5,4-d]pyrimidine compounds (compound 32) are more powerful than dipyridamole in two exceptionally metastatic cell models of breast malignancy in vitro. Future investigations will survey their helpful viability against bosom and different malignant growths with over-articulation of h-prune, an imprompt, evidence of idea, and creature models [35].<smiles>[R]c1nc(NCc2ccc(OC)cc2)c2nc([R])nc(NCc3ccc(OC)cc3)c2n1</smiles><smiles>OCC1CCCNC1</smiles>

It was accounted for that a series of 5-arylthieno[2,3- $d$ ]pyrimidines as anti-BC specialists. Compounds $\mathbf{3 3}$ and $\mathbf{3 4}$ with $\mathrm{IC}_{50} 9.8$ and $10.2 \mathrm{nM}$ individually were the most active compounds, on the whole, the tried mixtures, in light of the profound association of these mixtures in the rear of ATP restricting site and the extra hydrophobic connection given by para and meta dimethoxy groups in $\mathbf{3 3}$ and para dimethylamino group in compound 34 [36].<smiles>COc1ccc(/C=N/NI)cc1OC</smiles><smiles>CS/C=C(\CS)c1ccc([N+](=O)[O-])cc1</smiles>

Novel pyrimidine phosphonate atoms were planned in order to restrain aromatase, an expected target of BC. The ligand-receptor complex of compound $\mathbf{3 5}$ showed the best docking score of $-15.776 \mathrm{kcal} / \mathrm{mol}$ among all. Henceforth, this compound was blended and tried in vitro against MDA-MB-231 adenocarcinoma BC cells, and it displayed astounding antiproliferative movement and instigated apoptosis [37].

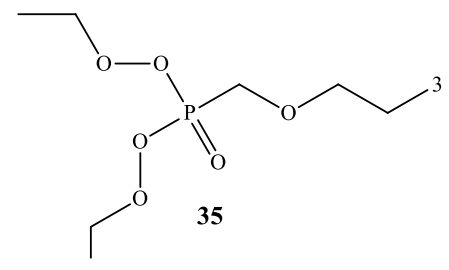


5- $\mathrm{COOCH}_{2} \mathrm{CH}_{3}, 6-\mathrm{CH}_{3}, 4-\mathrm{Ph}(4-\mathrm{OH}), 2-=\mathrm{O}$

A group of 3-(phenyl ethynyl)-1H-pyrazolo[3,4- $d$ ]pyrimidin-4-amine derivatives were planned and prepared. Compound 36 showed the most noteworthy inhibitory intensity against the Src kinase and the most strong antiviability action against the average TNBC cell line MDA-MB-231 among every one of the synthesized compounds. Further kinase hindrance assay showed that this compound was a multikinase inhibitor and intensely fundamentally repressed $\mathrm{Src}\left(\mathrm{IC}_{50}=0.9 \mathrm{nM}\right)$ and MAPK flagging and especially incited apoptosis in tumor tissues [38].

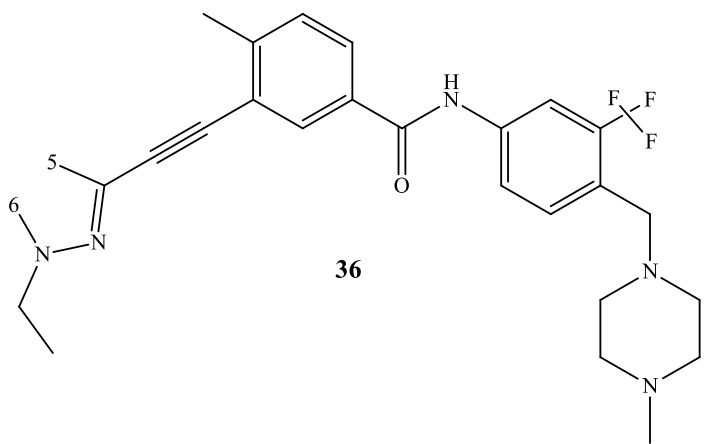

4- $\mathrm{NH}_{2}, 4-\mathrm{Ph}(4-\mathrm{OH}), 5-\mathrm{COOHCH}_{2} \mathrm{CH}_{3}, 6-\mathrm{CH}_{3}$

The present examination portrays a basic water-ethanol-intervened arrangement of combinatorial synthesize of 2-amino-4-phenyl-5H-indeno[1,2- $d$ ]pyrimidine-5-one subordinates. The chose integrated mixtures have been screened against the human BC cell line MCF-7, human colon malignancy cell line HT29, and typical viro monkey cell line, out of which compound $37\left(\mathrm{GI}_{50}=22.8 \mu \mathrm{M}\right)$ exhibited critical power toward human BC cell line (MCF-7) [39].<smiles>O=C(S)c1ccccc1I</smiles>

37

$2-\mathrm{NH}_{2}, 4-\mathrm{Ph}\left(4-\mathrm{OCH}_{3}\right)$

Halogenated thieno[3,2d]pyrimidines (38 and 39) with $\mathrm{IC}_{50}$ estimation of 9 and 5.9 $\mu \mathrm{M}$ respectively are both poisonous to the TNBC cell model MDA-MB-231 at lowmicromolar focuses, yet that just for compound 38 can specifically trigger mitotic capture [40].

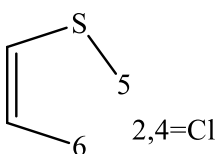

38

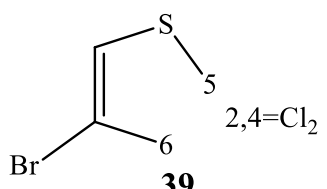


An epic thiazolopyrimidinone arrangement of phosphatidylinositol 3-kinase (PI3K)particular beta inhibitors have been identified. This chemotype has given an amazing apparatus compound, 40 (IC50 $1 / 422.8 \mathrm{mM}$ ), that showed powerful development hindrance in the PTEN-lacking MDA-MB-468 breast cell under port autonomous conditions, and it likewise exhibited pharmacodynamic impacts and viability in a PTEN inadequate prostate malignancy PC-3 xenographic mouse model [41].

1-Ph(2-Me,3-CF3),2-Me,4-=O ,

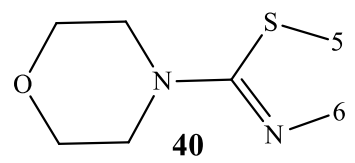

In the current examination, a progression of novel triazole-connected $N$-(pyrimidin-2yl)benzo[d]thiazol-2-amine were combined and assessed for anti-cancer activity against MCF-7 BC cells. Among the derivatives tried, promising compounds 41-44, under the concentration of $3,3.2,2.52$, and $2.12 \mu \mathrm{M}$, respectively, caused the most noteworthy cytotoxicity against MCF-7 $\mathrm{BC}$ cells by initiating apoptosis and influencing the articulation of key proteins like ERK1/2, NF-B, and surviving that cause abnormal cell multiplication and up-control the movement of caspase-9 [42].<smiles>CN(Cc1cn(CC(=O)Nc2ccc(F)cc2F)nn1)C1Nc2ccccc2S1</smiles><smiles>CCCCCOCCNC(=O)Cn1cc(CN([Al])c2nc3ccccc3s2)nn1</smiles><smiles>CCCCCCCCCCCCCCCCCC(C)(C)NC(=O)Cn1cc(CN(C)c2nc3ccccc3s2)nn1</smiles>

One compound, 8-cyclopentyl-2-[4-(4-methyl-piperazin-1-yl)-phenylamino]-7-oxo7,8-dihydro-pyrido[2,3d]pyrimidine-6-carbonitrile (45) incited development capture of most tumor cell lines, including a board of BC cell lines, with GI50 esteems going from 
0.025 to $2 \mathrm{mM}$, as a potent inhibitor of cyclin-dependent kinase 4 (CDK4) and AMPKRelated Kinase 5 (ARK5) [43].
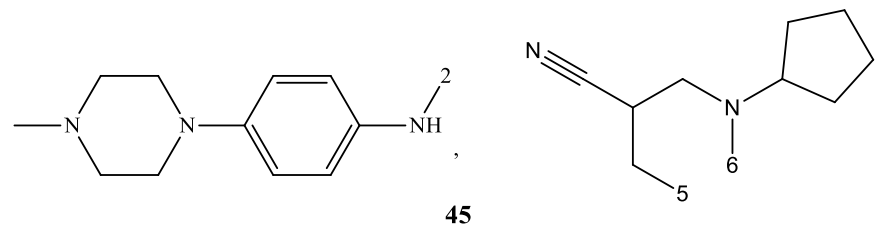

45

\section{The Indole Functional Group}

As perhaps the most pervasive heterocycles in nature, an indole ring framework has been turning into a significant underlying segment in numerous drug specialists, like anticonvulsant, antifungal, antiviral and hostile to inflammatory, especially in disclosure of new antitumor agents [49]. Indoles have promising anti-cancer potential; there has been accentuation on the combination of indole derivatives to beat issues looked at by existing remedial agents [50]. An assortment of indole derivatives, for example, isatin, have likewise been investigated for their anti-cancer activity. Additionally, indoles have promising inhibition on malignant growth potential; there has been the accentuation on the combination of indole derivatives to defeat issues looked at by existing therapeutic agents [45-48].<smiles>c1ccc2[nH]ccc2c1</smiles>

In the current examination, spiro[azetidine-2, 3'- indole]-2', 4(1'H)- dione subordinates were assessed for cytotoxicity against HEK-293T (human erythrocyte kidney cell line), MDAMB453 (human breast carcinoma cell line), MDA-MB468 (human breast carcinoma cell line, NCI-H522 (human lung cancer cell line) and NCI-H23 (human lung cancer cell line) with use of short term cytotoxicity MTT and XTT assay. The $\mathrm{IC}_{50}$ was examined by statistical analysis using GraphPad Prism application by plotting the log concentration vs. \% growth inhibition and dose-response curve analysis. Compound 46 displayed significant cytotoxicity $\left(\mathrm{IC}_{50}\right)$ in breast cancer cell lines after $48 \mathrm{~h}$ compared with the standard control drug doxorubicin and is a good candidate for developing novel drugs based on these derivatives [49].<smiles>Cc1ccccc1N1CC(C)C12C(=O)Nc1ccccc12</smiles>

They designed and synthesized novel bis-indole series as Topsentin. Nortopsentin analogs configuration depends on reestablishing the heterocyclic spacer in the regular 
leads by a further graceful hydrazide linker while pairing the two distant indole rings. All the synthesized bis-indoles were studied for their rapid-growth inhibitory action against human breast cancer (MCF-7 and MDA-MB-231) cell lines. The most potent congeners 47 and 48 against MCF-7 cells $\left(\mathrm{IC}_{50}=0.44 \pm 0.01\right.$ and $1.28 \pm 0.04 \mu \mathrm{M}$, respectively) induced apoptosis in MCF-7 cells (23.7-, and 16.8-fold development in the total apoptosis percentage) as obvious by the externalization of plasma membrane phosphatidylserine noted by Annexin V-FITC/PI assay. This proof was held up by the Bax/Bcl-2 ratio augmentation (18.65- and 11.1-fold compared to control) with a concomitant growth in the level of caspase-3 (11.7- and 9.5-fold) and p53 (15.4- and 11.75-fold). Both compounds halted the cell cycle, mainly in the G2/M stage. Additionally, these compounds showed excellent selectivity toward tumor cells (SI = 38.7 and 18.3), after testing their cytotoxicity toward non-tumorigenic MCF-10A cells. Finally, compounds 47a-d and 48 were tested for their credible CDK2 inhibitory action. The acquired results (\% inhibition range: $16 \%-58 \%$ ) uncovered the inability of the target bis-indoles to stop CDK2 noteworthy. Generally, these results recommended that herein detailed bis-indoles are promising lead compounds for further optimization and expansion as potential efficient anti-breast cancer drugs [50].

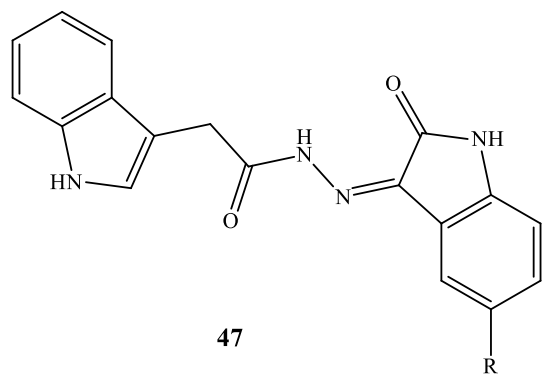

a) $\mathrm{R}=\mathrm{F}$, b) $\mathrm{R}=\mathrm{Cl}$, c) $\mathrm{R}=\mathrm{Me}$ and d) $\mathrm{R}=\mathrm{NO}_{2}$

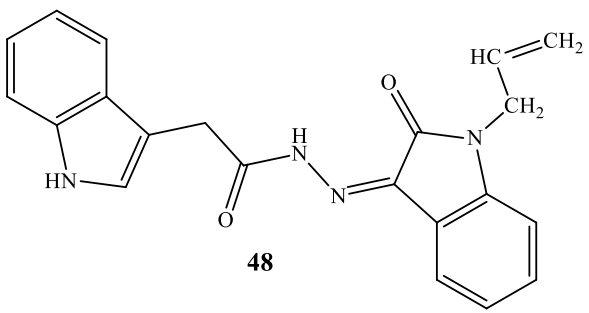

A series of new isatin-thiazoline and isatin-benzimidazole derivatives were synthesized via condensation of isatin Mannich bases with either 2-aminothiazoline or 2aminobenzimidazole. The structures of the newly synthesized compounds were characterized by spectral data. The anti-breast cancer activity of some of the synthesized compounds was assessed in the MCF-7 human breast cancer cell line. The results showed that compound 49a-c possesses significant antiproliferative activity against MCF-7 cells [51]. 
<smiles>[R1]N([R3])CN1C(=O)/C(=N\c2nc3ccccc3[nH]2)c2ccccc21</smiles>

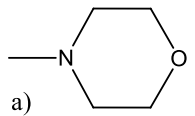

a)

c)<smiles>CN(c1ccccc1)c1ccccc1</smiles>

b)

A series of novel indolylquinones have been synthesized by treating halogenoquinone with 2-substituted indole derivatives within sight of kalium carbonate and TEBA in acetonitrile at room temperature. These compounds were assessed for their antiproliferative action against human MDA-MB-231 and MCF-7 breast malignancy cell lines. Every tested compound showed powerful micromolar cytotoxicity movement in both breast's malignant growth cell lines. $3 \mathrm{~d}\left(\mathrm{IC}_{50}=2.29 \mathrm{mg} / \mathrm{mL}\right.$ for MCF-7 cells $)$ and $\mathbf{5 0}$ \& $51\left(\mathrm{IC}_{50}=3.99 \mathrm{mg} / \mathrm{mL}\right.$ for MDA-MB-231 cells) showed the most strong antiproliferative action of the arrangement. Additionally, in vitro anti-cancer action of the compounds further showed that bis-indolylquinones were more dynamic than monoindolylquinones. Fluorescence microscopy examination showed that compounds $\mathbf{5 0}$ and 51 restrained disease cell expansion by setting off apoptotic cell death [52].<smiles>Cc1[nH]c2ccccc2c1C1=C(Cl)C(=O)C(c2c(-c3ccccc3)[nH]c3ccccc23)=C(Cl)C1=O</smiles><smiles>COc1ccc2[nH]c(C)c(C3=C(Br)C(=O)C(c4c(-c5ccc(C)cc5)[nH]c5ccccc45)=C(Br)C3=O)c2c1</smiles> 
A most up-to-date arrangement of 3-(2-oxo-2-phenylethylidene)indolin-2-ones work in pharmacophoric components of isatins and chalcones was laid out and combined, and evaluated for anti-cancer activity against three BC cell lines. In all the promising compounds, compound $\mathbf{5 2}$ was found to be the most active in the series with $\mathrm{GI}_{50}$ values of 8.54, 4.76, and 3.59 $\mu \mathrm{M}$ against MDA-MB-231, MDA-MB-468, and MCF-7 cells, respectively [53].

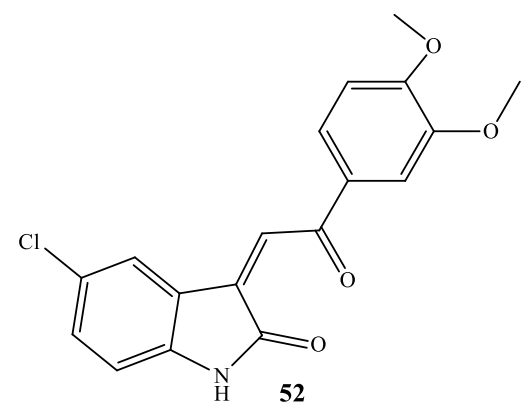

In this study, the preparation of a newer phemindole (53) synthetic aryl methyl ringsubstituted analog of 3,3'-diindolyl methane $\left(\mathrm{IC}_{50}=10.85\right)$ was reported as an effective antitumor agent against MDAMB-231 cells through actuating apoptosis and confined the in vitro cell relocation through its antimitotic property and the phosphorylation of central bond kinase guideline in MDAMB-231 cells. Furthermore, studies extended to ex vivo and in vivo mice models further validated the efficacy of phemindole [54].

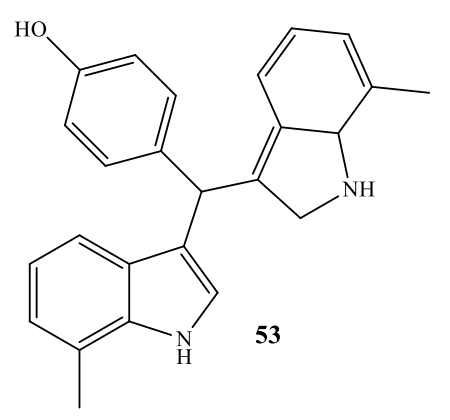

Some indeno[ $\left[1,2_{\mathrm{b}}\right]$ indole-9,10-dione compounds were integrated as human casein kinase II (CK2) inhibitors. Look at the general capacity of each compound to repress CK2; compound $54\left(\mathrm{IC}_{50} 1 / 425 \ldots 10 \_3 \mathrm{mM}\right)$ has an unmistakable antiproliferative impact against MCF-7 BC cells and was about significant degrees more selective [55]. 


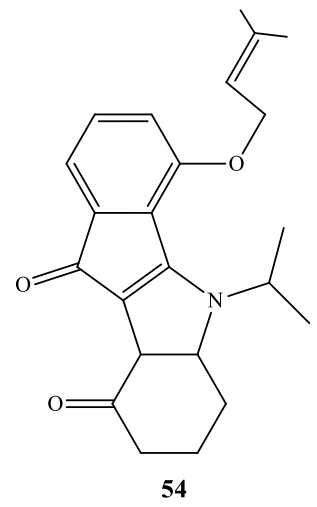

The indole alkaloid meleagrin (55) $\mathrm{IC}_{50}$ estimation of $1.9,6.8,8.9,2.7$, and $2.8 \mathrm{mM}$ separately, for MCF-7, MDA-MB-231, MDA-468, BT-474, and SKBR-3, from the olive tree endophytic parasite Penicillium chrysogenum, was distinguished as a huge wild and freak c-Met inhibitor. This was connected with antiproliferative, anti-migratory, and hostile to intrusive exercises against a wide board of c-Met subordinate BC cells, including all cell lines, yet was dormant against the c-Met free BC cells [56].

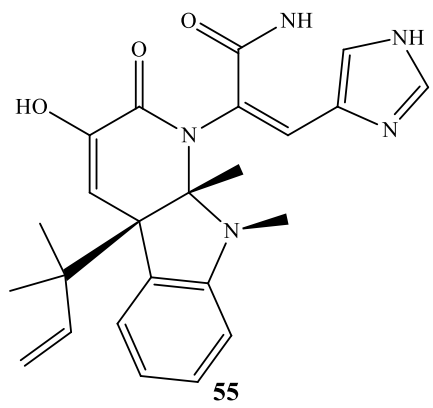

An examination planned and generated novel neotanshinlactone analogs to utilize bioisosterism and sub-atomic alteration and to assess their bioactivity against BC specialists. Compound 56 has been tried for the three non-BC cell lines and the triplenegative $\mathrm{BC}$ cell lines, yet has displayed no critical cytotoxicity with the normal $\mathrm{IC}_{50}$ being more prominent than $34 \mathrm{mM}$, contrasted with neo-tanshinlactone and 4-ethyl neotanshinlactone, and the selectivity towards BC has additionally diminished [57].

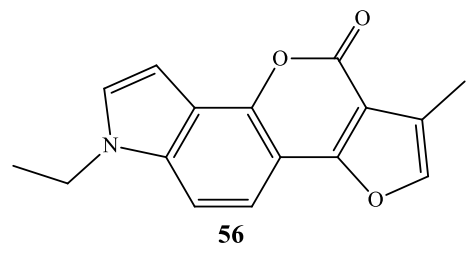

An arrangement of novel benzothiazole derivatives bearing indole-based moiety was planned, blended, and evaluated for in vitro antitumor action against four threat cell lines. Compound 57 displayed incredible antitumor action with IC50 estimations of 0.024, 0.29, 
0.84 and $0.88 \mathrm{mM}$ against HT29, H460, A549 and MDA-MB-231, individually. What is more, the checked pharmacological movement of compound $\mathbf{5 7}$ may be credited to the enactment of procaspase-3 and cell cycle arrest [58].

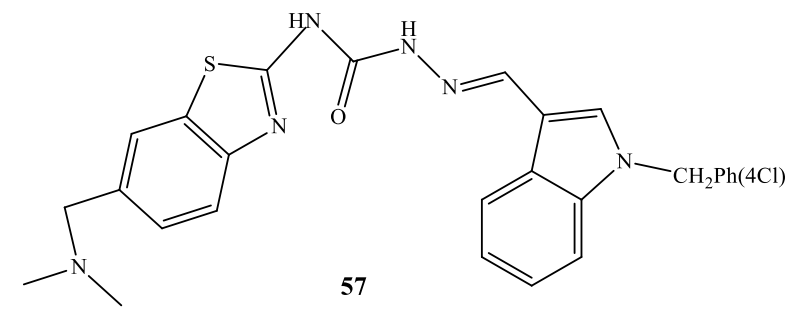

A series of novel indolylquinones have been synthesized and assessed for their antiproliferative activity against human MDA-MB-231 and MCF-7 BC cell lines. Among every derivative, $\mathbf{5 8}$ (IC50 esteem $1 / 42.29 \mathrm{mg} \mathrm{mL} 1$ for MCF-7 cells) and $\mathbf{5 9}$ (IC50 =3.99 $\mathrm{mg} / \mathrm{mL}$ for MDA-MB-231 cells) showed the most powerful antiproliferative action of these compounds and hindered BC cells multiplication by setting off apoptotic cell death [59].

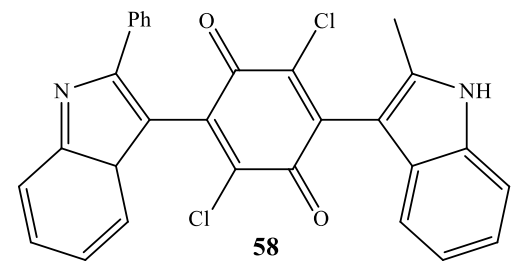

58

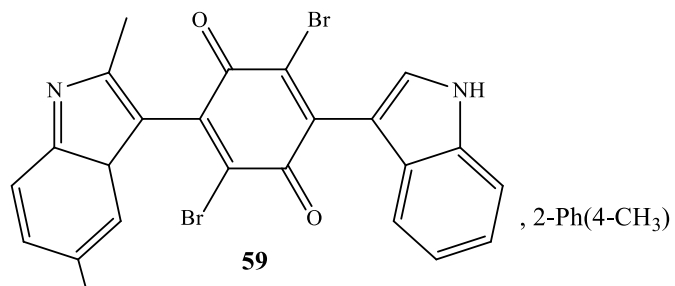

59

The design, synthesis, inhibitory strength in vitro and pharmacokinetic profiles of Ko143 analogs are portrayed. Contrasted with usually utilized Ko143, the new BCRP inhibitor (compound 60) showed a similar power and a fundamentally improved pharmacokinetic profile in rats [60].

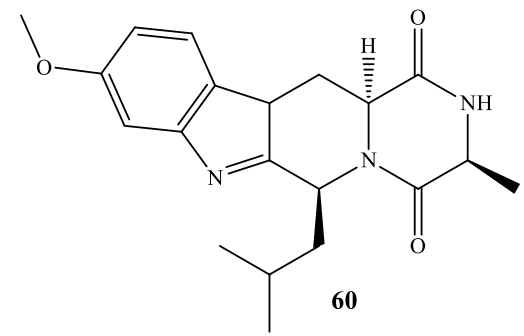

A series of ten novel satin analogs have been synthesized and screened in vitro for their anti-BC activity against the MCF-7 cell line. All the tested compounds showed highly potent activity against MCF-7 cell line, with especially compounds 61-64 exhibited 
demonstrative antiproliferative effects on MCF-7 BC cell line compared to reference adriamycin (doxorubicin) and $\mathrm{GI}_{50}<0.02 \mathrm{mM}[61]$.
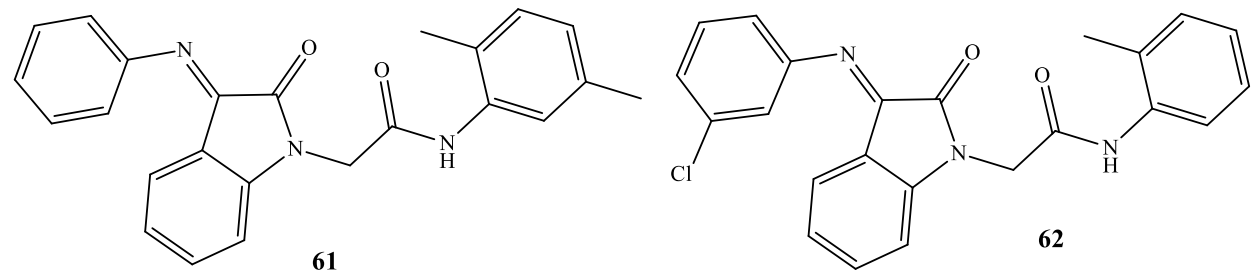<smiles>O=C(CN1C(=O)/C(=N/c2ccc(Cl)cc2)c2ccccc21)Nc1ccccc1</smiles><smiles>Cc1ccccc1NC(=O)CN1C(=O)/C(=N/c2ccc(Cl)cc2)c2ccccc21</smiles>

\section{Future Perspective}

Due to the sudden changes in peoples' lifestyles, more and more patients were diagnosed with BC. Early treatment and early diagnosis were promoted due to the increased number of patients. Some helpful self measures are taken, like participation in an exercise and diet counseling program, which lead to loss of body fat, improved fitness and quality of life, and increased habitual physical activity in BC survivors. BC patients undergoing breast-conserving therapy had a better outcome than modified radical mastectomy. Chemical treatment is always vital because of its advantages, including higher rates of breast-conserving surgery and the possibility of measuring early in vivo responses to systemic therapy. From this study, we noted that that nitrogen-containing heterocycle shows a potent anti-breast cancer activity. This can be taken as a good scope for future study. Hence, the discovery of novel compounds is more important, with promising anti-BC properties, which may be proven to be more effective and selective, and are much freer of unwanted side effects. 


\section{Acknowledgment}

The authors are thankful to the GRACE COLLEGE OF PHARMACY management, Palakkad, to provide all facilities for the present investigation.

\section{References}

1. M. A. E. Hamid, M. Mihovilovic, and H. El-Nassan, Eur. J. Med. Chem. 57, 323 (2012). https://doi.org/10.1016/j.ejmech.2012.09.031

2. J. Manivel, S, Sangeetha, and M. Murali, J. Sci. Res. 12, 111 (2020). https://doi.org/10.3329/jsr.v12i1.42745

3. S. Ravi, C. Bandana, S. Uma, I. Mohd, D. Shreekant, S. K. D. Dwivedi, H. K. Bid, R. Konwar, G. Kharkwal, V. Chandra, A. D. wivedi, and K. Hajela. Bioorg. Med. Chem. 177, 3847 (2009). https://doi.org/10.1016/i.bmc.2009.04.032

4. T. Saroja, R. M. Ezhilarasi, V. Selvamani, and S. Mahalakshmi. J. Sci. Res. 13, 183 (2021). https://doi.org/10.3329/jsr.v13i1.46995

5. E. Ahmed, A. Sarhan, D. El-Naggar, R. Khattab, M. El-Naggar, S. El-Messery, G. Hassan, M. M. Mounier, K. Mahmoud, N. I. Ali, and K. F. Mahrous, Bioorg. Chem. 93, ID 103332 (2019). https://doi.org/10.1016/j.bioorg.2019.103332

6. S. Pareek, Y. Huang, A. Nath, and R. Huang (Academic Press, 2020) pp. 173-190. https://doi.org/10.1016/B978-0-12-819668-7.00006-3

7. D. Dawood, E. Nossier, M. Ali, and A. Mahmoud, Bioorg. Chem. 101, 103 (2020). https://doi.org/10.1016/j.bioorg.2020.103916

8. M. Theodoulou and A. D. Seidman, Seminars in Oncol. 30, 730 (2003). https://doi.org/10.1053/i.seminoncol.2003.08.024

9. Y. Feng, M. Spezia, S. Huang, C. Yuan, Z. Zeng, L. Zhang, X. Ji, W. Liu, B. Huang, W. Luo, and B. Liu, Genes Diseases 5, 77 (2018). https://doi.org/10.1016/j.gendis.2018.05.001

10. M. Ghorab and M. Alsaid, Acta Pharmaceutica 65, 271 (2015). https://doi.org/10.1515/acph-2015-0030

11. P. O'Neill and S. Ward, Angew. Chem. Int. Ed. 54, 13504 (2015). https://doi.org/10.1002/anie.201507264

12. R. A. Al-Qawasmeh, B. B. Huthail, M. O. Sinnokrot, M. H. Semreen, R. A. Odeh, M. H. AbuZarga, H. Tarazi, I. A. Yousef, and T. H. Al-Tel, Med. Chem. 12, 563 (2016). https://doi.org/10.2174/1573406412666160518142441

13. S. Cretton, S. Dorsaz, A. Azzollini, Q. Favre-Godal, L. Marcourt, S. N. Ebrahimi, F. Voinesco, E. Michellod, D. Sanglard, K. Gindro, and J. L. Wolfender, J. Natur. Product. 79, 300 (2016). https://doi.org/10.1021/acs.jnatprod.5b00896

14. X. Deng, M. Song, Y. Zheng, and Z. Quan, Eur. J. Med. Chem. 73, 217 (2014). https://doi.org/10.1016/j.ejmech.2013.12.014

15. S. K. Gupta and A. Mishra, Anti-Inflamm. Anti-Allergy Agents Med. Chem. 15, 31 (2016). https://doi.org/10.2174/1871523015666160210124545

16. L. Yin, Q. Hu, and R. Hartmann, J. Med. Chem. 56, 460 (2013). https://doi.org/10.1021/jm301408t

17. R. Ghodsi, E. Azizi, M. G. Ferlin, V. Pezzi, and Zarghi, Lett. Drug Design Discovery 13, 89 (2016). https://doi.org/10.2174/1570180812666150611185605

18. R. Viswas, S. Pundir, and H. Lee. J. Enzyme Inhib. Med. Chem. 34, 620 (2019). https://doi.org/10.1080/14756366.2019.1571055

19. F. Jafari, H. Baghayi, P. Lavaee, F. Hadizadeh, F. Soltani, H. Moallemzadeh, S. Mirzaei, S. M. Aboutorabzadeh, and R. Ghodsi, Eur. J. Med. Chem. 164, 292 (2019). https://doi.org/10.1016/j.ejmech.2018.12.060

20. Y. Liu, H. Chen, C. Tzeng, P. Lu, C. Lo, Y. Lee, C. Tseng, Y. Chen, C. Yang, Breast Cancer Res. Treatment 138, 383 (2013). https://doi.org/10.1007/s10549-013-2441-1 
21. C. Tseng, Y. Chen, C. Hsu, T. Chen, C. Cheng, H. Tso, Y. Lu, C. Tzeng, Eur. J. Med. Chem. 59, 274 (2013). https://doi.org/10.1016/j.ejmech.2012.11.027

22. C. Tseng, C. Tzeng, C. Yang, P. Lu, Y. Liu, H. Chen, C. Chen, C. Yang, and Y. Chen, Mol. Diversity 17, 781 (2013). https://doi.org/10.1007/s11030-013-9475-5

23. N. Mohammadhosseini, M. Pordeli, M. Safavi, L. Firoozpour, F. Amin, S. K. Ardestani, N. Edraki, A. Shafiee, and A. Foroumadi, Iran. J. Pharm. Res. 14, 1095 (2015). https://www.ncbi.nlm.nih.gov/pubmed/26664376

24. L. Bheemanapalli, A. Kaur, R. Arora, R. Akkinepally, and N. Javali, Med. Chem. Res. 21, 1741 (2012). https://doi.org/10.1007/s00044-011-9688-Z

25. E. Leung, J. Hung, D. Barker, and J. Reynisson, Med. Chem. Comm. 5, 99 (2014). https://doi.org/10.1039/C3MD00290J

26. A. Zarghi, R. Ghodsi, and E. Azizi, Iran. J. Pharm. Res. 15, 169 (2016). https://doi.org/10.2174/1570180812666150611185605

27. Q. Hu, L. Yin, and R. Hartmann, J. Med. Chem. 55, 7080 (2012). https://doi.org/10.1021/jm3004637

28. H. Bharathkumar, C. D. Mohan, H. Ananda, J. E. Fuchs, F. Li, S. Rangappa, M. Surender, K. C. Bulusu, K. S. Girish, G. Sethi, and A. Bender, Bioorg. Med. Chem. Lett. 25, 1804 (2015). https://doi.org/10.1016/j.bmcl.2015.01.030

29. R. Kaur, P. Kaur, S. Sharma, G. Singh, S. Mehndiratta, P. M. S. Bedi, and K. Nepali, Rec. Patents Anti-cancer Drug Discovery 10, 23 (2015). https://doi.org/10.2174/1574892809666140917104502

30. Z. Nofal, H. Fahmy, E. Zarea, and W. El-Eraky, Acta Pol. Pharm. 68, 507 (2011).

31. S. Rahaman, Y. Pasad, P. Kumar, and B. Kumar, Saudi Pharm. J. 17, 255 (2019). https://doi.org/10.1016/j.jsps.2009.08.001

32. J. Rani, S. Kumar, M. Saini, J. Mundlia, and P. Verma, Res. Chem. Intermed. 42, 6777 (2013). https://doi.org/10.1007/s11164-016-2525-8

33. A. El-Ansary, A. Kamal, and M. Al-Ghorafi, Eur. J. Med. Chem. 86, 202 (2014). https://doi.org/10.1016/j.ejmech.2014.08.056

34. A. Kassab and E. Gedawy, Eur. J. Med. Chem. 63, 224 (2013). https://doi.org/10.1016/j.ejmech.2013.02.011

35. K. Mohammed, D. Marko, and B. Hala, Eur. J. Med. Chem. 57, 323 (2012). https://doi.org/10.1016/j.ejmech.2012.09.031

36. G. Maryam, B. Kachigere, D. Chakrabhavi, R. Ainiah, and R. Shobith, Bioorg. Med. Chem. Lett. 28, 2314 (2018). https://doi.org/10.1016/j.bmcl.2018.05.020

37. E. Aymn, E. Abeer, and M. Mamdouh, Eur. J. Med. Chem. 46, 1019 (2011). https://doi.org/10.1016/j.ejmech.2011.01.013

38. A. Virgilio, D. Spano, V. Esposito, V. Di Dato, G. Citarella, N. Marino, V. Maffia, D. De Martino, P. D. Antonellis, A. Galeone, and M. Zollo, Eur. J. Med. Chem. 57, 41 (2012). https://doi.org/10.1016/j.ejmech.2012.08.020

39. El-Ansary, A. Kamal, and M. Al-Ghora, Eur. J. Med. Chem. 86, 202 (2014). https://doi.org/10.1016/j.ejmech.2014.08.056

40. N. Yellapu, N. Atluri, K. Kandlapalli, R. Kilaru, R. Vangavaragu, H. Osuru, N. Chamarthi, P. Sarma, and B. Matcha, Med. Chem. Res. 23, 317 (2014). https://doi.org/10.1007/s00044-013-0628-y

41. C. H. Zhang, M. W. Zheng, Y. P. Li, X. D. Lin, M. Huang, L. Zhong, G. B. Li, R. Zhang, W. T. Lin, Y. Jiao, R. Xiang, J-Chen, Y. Zhao, W. Cheng, Y.-Q. Wei, and S.-Y. Yang, J. Med. Chem. 58, 3957 (2015). https://doi.org/10.1021/acs.jmedchem.5b00270

42. A. Patravale, A. Gore, D. Patil, G. Kolekar, M. Deshmukh, and P.V. Anbhule, Ind. Eng. Chem. Res. 53, 16568 (2014). https://doi.org/10.1021/ie5013618

43. C. Ross, K. Temburnikar, G. Wilson, and S. Radtke. Bioorg. Med. Chem. Lett. 25, 1715 (2015). https://doi.org/10.1016/j.bmcl.2015.02.071 
44. H. Lin, M. Schulz, R. Xie, J. Zeng, J. I. Luengo, M. D. Squire, R. Tedesco, J. Qu, K. Erhard, J. J. Mack, K. Raha, R. Plant, C. Rominger, J. Ariazi, C. S. Sherk, and M. Schaber, ACS Med. Chem. Lett. 3, 524 (2012). https://doi.org/10.1021/ml300045b

45. M. Kumbhare, T. Dadmal, M. Ramaiah, K. Kishore, P. Valli, S. Tiwari, K. Appalanaidu, Y. Rao, and M. Bhadra, Bioorg. Med. Chem. Lett. 25, 654 (2015). https://doi.org/10.1016/j.bmcl.2014.11.083

46. M. Reddy, B. Akula, S. Cosenza, S. Athuluridivakar, Mallireddigari, V. Pallela, V. Billa, D. V. Subbaiah, E. Bharathi, V. Carpio, A. Padgaonkar, S. Baker, and E. P. Reddy, J. Med. Chem. 57, 578 (2014). https://doi.org/10.1021/jm401073p

47. P. Ahuja and N. Siddiqui, Eur. J. Med. Chem. 80, 509 (2014). https://doi.org/10.1016/j.ejmech.2014.04.043

48. M. Zhang, N. Mulholland, D. Beattie, D. Irwin, Y. Gu, Q. Chen, G.-F. Yang, and J. Clough, Eur. J. Med. Chem. 63, 22 (2013). https://doi.org/10.1016/j.ejmech.2013.01.038

49. M. Zhang, Q. Chen, and G. F. Yang, Eur. J. Med. Chem. 89, 421 (2014). https://doi.org/10.1016/j.ejmech.2014.10.065

50. N. Singh, U. Singh, M. Rouse, J. Zhang, S. Chatterjee, P. Nagarkatti, and M. Nagarkatti, J. Immunol. 196, 1108 (2016). https://doi.org/10.4049/jimmunol.1501727

51. S. Pedada, N. Yarla, P. Tambade, B. Dhananjaya, A. Bishayee, K. Arunasree, G. Philip, G. Dharmapuri, and G. Rangaiah, Eur. J. Med. Chem. 112, 289 (2016). https://doi.org/10.1016/j.ejmech.2016.02.025

52. J. S. Singh, R. Singla, and V. Jaitak, Anti-cancer Agents Med. Chem. 16, 160 (2016). https://doi.org/10.2174/1871520615666150520144217

53. S. Prakash, S. Poonam, R. Sonal, A. Sarav, and P. Maulik, Scholars Res. Libr. 3, 236 (2011).

54. M. Wagdy, S. Ghada, T. Sara, M. Hamad, A. Abdulrahman, and H. Ghada, Marine Drugs. 18, 190 (2020). https://doi.org/10.3390/md18040190

55. T. Azza, A. Nadia, and M. Eman, Arch. Pharm. Res. 34, 1615 (2011). https://doi.org/10.1007/s12272-011-1005-3

56. C. Karthikeyan, V. Solomon, H. Lee, and P. Trivedi, Biomed. Preven. Nutri. 3, 325 (2013). https://doi.org/10.1016/j.bionut.2013.04.001

57. S. Chakraborty, S. Ghosh, B. Banerjee, A. Santra, A. Adhikary, A. K. Misra, and P. C. Sen, Front. Pharmacol. 7, 114 (2016). https://doi.org/10.3389/fphar.2016.00114

58. G. J. Gozzi, et al. J. Med. Chem. 58, 265 (2015). https://doi.org/10.1021/jm500943z

59. M. Mady, M. Mohyeldin, H. Ebrahim, H. Elsayed, W. Houssen, E. Haggag, R. Soliman, and K. E. Sayed, Bioorg. Med. Chem. 24,113 (2016). https://doi.org/10.1016/j.bmc.2015.11.038

60. J. Brattlie, Progress Towards the Design and Synthesis of Novel Antitumor NeoTanshinlactone Analogues, (The University of North Carolina at Chapel Hil. 2014). https://doi.org/10.17615/d56y-1y20

61. J. Ma, G. Bao, L. Wang, W. Li, B. Xu, B. Du, J. Lv, X. Zhai, and P. Gong, Eur. J. Med. Chem. 96, 173 (2015). https://doi.org/10.1016/j.ejmech.2015.04.018

62. X. Li, S. L. Zheng, X. Li, J. L. Li, O. Qiang, R. Liu, and L. He, Eur. J. Med. Chem. 54, 42 (2012). https://doi.org/10.1016/j.ejmech.2012.04.019

63. Y. Li, J. Woo, J. Chmielecki, C. Xia, M. Liao, B. C. Chuang, J. J. Yang, M. Y. Guan, M. Plesescu, and S. R. Prakash, Bioorg. Med. Chem. Lett. 26, 551 (2016). https://doi.org/10.1016/j.bmcl.2015.11.077 